\title{
Comparative evaluation of ventilatory function through pre and postoperative peak expiratory flow in patients submitted to elective upper abdominal surgery
}

\author{
Avaliação comparativa da função ventilatória através do pico de fluxo \\ expiratório no pré e pós-operatório imediatos de pacientes submetidos a \\ procedimentos cirúrgicos eletivos de andar superior de abdome
}

Caio Fernando Cavanus Scheeren ${ }^{1}$; José Júlio Saraiva Gonçalves ${ }^{1}$.

\begin{abstract}
A B S T R A C T
Objective: to evaluate the ventilatory function by Peak Expiratory Flow (PEF) in the immediate pre and postoperative periods of patients undergoing elective surgical procedures in the upper abdomen. Methods: we conducted a prospective cohort study including 47 patients admitted to the Hospital Regional de Mato Grosso do Sul from July to December 2014, who underwent elective surgeries of the upper abdomen, and submiited to spirometric evaluation and measurement of PEF immediately before and after surgery. Results: of the 47 patients, $22(46.8 \%)$ were male and 25 (53.20\%) female. The mean preoperative PEF was $412.1 \pm 91.7$, and postoperative, $331.0 \pm 87.8$, indicating significant differences between the two variables. Men had higher PEF values than women, both in the pre and postoperative periods. There was a reasonable inverse correlation between age and decreased PEF. Both situations showed statistical significance $(p<0.001)$. The group of smokers had lower PEF values both before and after surgery. The group of patients with comorbidities (hypertension and/or diabetes) showed lower PEF values both pre and postoperatively $(p=0.005)$. In both groups, surgery resulted in a significant decrease in PEF $(p<0.001)$. The type of surgery performed and the type of anesthesia did not show significant differences. Conclusion: the variables most involved in decreased lung function were: advanced age, smoking and presence of comorbidities. However, there is no consistent evidence to suggest conducting routine spirometry in such patients.
\end{abstract}

Keywords: Peak Expiratory Flow Rate. Surgery. Smoking. Thoracic Surgery. Elective Surgical Procedures.

\section{INTRODUCTION}

$\mathrm{P}$ ulmonary complications are frequent in any surgery postoperative period, but their incidence is higher in thoracic and abdominal surgeries performed above the umbilicus ${ }^{1}$.

The occurrence of these complications closely relates to the existence of preoperative risk factors that are widely studied in the literature. Among them are: advanced age, presence of pulmonary disease or other medical illnesses, smoking and its intensity, obesity, malnutrition, type of anesthesia, duration of surgery and surgical technique, abnormal spirometric values, decreased ability to exercise and prolonged preoperative hospitalization time ${ }^{1,2}$.

Lung function tests done prior to surgery have been used for decades to assist in estimating sur- gical risk ${ }^{3}$. Spirometry measures the volume of inhaled and exhaled air and respiratory flows, being especially useful in the analysis of data derived from forced expiratory maneuver and the peak expiratory flow (PEF). The latter is the clinically most useful measure of lung function ${ }^{4}$.

This study aimed to compare the PEF measurements in the pre and immediate postoperative periods of patients undergoing elective surgeries of the upper abdomen, correlating them with some variables, such as smoking and comorbidities.

\section{METHODS}

After approval by the Ethics in Research Committee of the Hospital Regional de Mato Grosso do Sul (HRMS), Protocol 27/2014, according to Resolution 466

1 - Serviço de Cirurgia Geral e torácica do Hospital Regional de Mato Grosso do Sul (HRMS), Mato Grosso do Sul, MS, Brasil. 
Table 1. Peak expiratory flow values before and after surgery, for both genders. Different letters indicate statistically distinct groups.

\begin{tabular}{lcc}
\hline & Male $(\mathrm{n}=22)$ & Gender \\
\cline { 2 - 3 } Preoperative PFE & $464.1 \pm 92.9 \mathrm{~A}$ & Female $(\mathrm{n}=25)$ \\
\cline { 2 - 4 } Postoperative PFE & $373.2 \pm 92.1 \mathrm{~B}$ & $366.4 \pm 62.6 \mathrm{~B}$ \\
\hline
\end{tabular}

of 12/12/2012, the Conselho Nacional de Saúde (CNS), we held a prospective cohort study. We evaluated 47 patients from May to December 2014.

We measured the PEF with a portable device, the Mini-Wright $₫$ Peak Flow Meter 3103 (Airmed), ranging from 60 to $850 \mathrm{l} / \mathrm{min}$, according to the Guidelines for Pulmonary Function Tests, 2002, with the patient sitting ${ }^{4}$. We instructed the patients to exert a maximal inspiration to total lung capacity followed by a maximal, short and explosive forced expiration through the measuring device, without extending the measure to residual volume. The expiratory effort needed last only a second or two. We repeated the test three times, considering the best result if the readings did not differ more than $20 \mathrm{l} /$ min from each other.

We provided an informed consent form, and evaluated the patients within 24 hours preoperatively and within the first 24 postoperative hours. We selected the patients according to the following criteria: a) all patients over 13 years old, admitted electively in HRMS to undergo upper abdominal surgery, and accepted, or the legal guardian authorized, to participate in the study. The Exclusion criteria were: a) patients younger than 13 years; b) patient who refused to participate in the study; c) patients admitted on an emergency basis; d) patients who failed to properly perform the lung function test in pre or postoperative periods; e) patients whose surgical procedure was changed for some reason; f) patients with some type of postoperative complication, such as the need for hospitalization in Intensive Care Unit (ICU) or need for prolonged intubation.

We compared the data using descriptive and analytical parametric statistics, ANOVA package. The programs used were GraphPad Prism version 6.01 and SPSS version 22.0 .

\section{RESULTS}

\section{Pre and Post-operative Peak Expiratory Flow Analysis}

The results of PEF analysis in the pre and postoperative periods of the 47 patients were mean \pm standard deviation - PEF pre $=412.1 \pm 91.7$; PEF post $=$ $331.0 \pm 87.8$.

The D'Agostino and Pearson Test (analysis of the distribution type) showed that the sample distribution was Gaussian, which authorized the use of a parametric test for statistical analysis.

The " $\mathrm{t}$ " test for paired data (analysis of differences between groups) showed significant differences between the pre and postoperative PEFs $(p<0.001)$.

\section{Correlation between groups}

The result of the Pearson test showed a correlation coefficient $\rho=0.967(p<0.001)$, indicating a strong and direct relationship between the two variables.

Table 2. Peak expiratory flow values before and after surgery, for the different age groups. Different letters indicate statistically distinct groups.

\begin{tabular}{lcc}
\hline & \multicolumn{2}{c}{ Faixa etária (anos) } \\
\cline { 2 - 3 } Age group & Preoperative PFE & Postoperative PFE \\
\cline { 2 - 2 } From 10 to 19 years $(n=1)$ & 460.0 & 391.0 \\
From 20 to 29 years $(n=11)$ & $469.1 \pm 94.6 \mathrm{~A}$ & $389.1 \pm 99.1 \mathrm{C}$ \\
From 30 to 39 years $(n=13)$ & $440.891 .1 \pm \mathrm{AB}$ & $351.5 \pm 77.6 \mathrm{CD}$ \\
From 40 to 49 years $(n=10)$ & $366.0 \pm 82.1 \mathrm{~B}$ & $294.5 \pm 79.0 \mathrm{D}$ \\
From 50 to 59 years $(\mathrm{n}=10)$ & $376.0 \pm 56.2 \mathrm{~B}$ & $294.0 \pm 55.2 \mathrm{D}$ \\
From 60 to 69 years $(\mathrm{n}=2)$ & $300.0 \pm 28.3 \mathrm{~B}$ & $215.0 \pm 21.2 \mathrm{D}$ \\
\hline
\end{tabular}


Table 3. Peak expiratory flow values before and after surgery, regarding smoking. Different letters indicate statistically distinct groups.

\begin{tabular}{lccc}
\hline & \multicolumn{2}{c}{ Smoking } \\
\cline { 2 - 3 } Preoperative PFE & No $(n=26)$ & & Yes $(n=21)$ \\
Postoperative PFE & $339.2 \pm 93.3 \mathrm{~A}$ & & $378.6 \pm 79.6 \mathrm{~B}$ \\
\hline
\end{tabular}

\section{Pre and Post-operative Peak Expiratory Flow Analysis and Other Variables}

\section{Gender}

The two-way analysis of variance (two-way ANOVA) detected differences between the experimental groups. The post-hoc Bonferroni test showed that males has higher PEF values than females in both pre and postoperatively $(p<0.001)$, as shown in Table 1 .

\section{Age Group}

The two-way analysis of variance (two-way ANOVA) detected differences between the experimental groups. The post-hoc Bonferroni test showed that all age groups have higher PEF values preoperatively than postoperatively $(p<0.001)$, as shown in Table 2 .

\section{Smoking}

The two-way analysis of variance (two-way ANOVA) detected differences between the experimental groups. The post-hoc Bonferroni test showed that the group of smokers had lower PEF values both pre and postoperatively $(p=0.008)$. In both groups, surgey determined a significant decrease in PEF $(p<0.001)$, as brought by Table 3.

\section{Comorbidities}

The two-way analysis of variance (two-way ANOVA) detected differences between the experimental groups. The post-hoc Bonferroni test showed that the group of patients with comorbidities had lower PEF values both pre and postoperatively $(p=0.005)$. In both groups, surgery determined a significant decrease in PEF $(p<0.001)$, as shown in Table 4.

\section{Postoperative PEF}

Analysis of variance showed no significant differences between the types of surgery performed and PEF $(p=0.055)$. Table 5 shows these values.

\section{Anesthetic technique and PEF}

The Mann-Whitney test showed no significant differences between the types of anesthesia used and postoperative PEF ( $p=0.178)$. Table 6 shows these values.

\section{DISCUSSION}

Postoperative Lung Complications (POLC) include atelectasis, pneumonia, bronchitis, bronchospasm, hypoxemia, respiratory failure and prolonged mechanical ventilation ${ }^{5}$. The incidence of POLC varies around $20 \%$ between studies ${ }^{6}$, but they are at least as common as cardiac complications as regards the abdominal surgeries ${ }^{7}$. The most important predictor for the development of POLC is the surgical site. The complication rate when the surgical incision is in the upper abdomen or chest varies between $10 \%$ and $40 \%$ of all cases, while staying between $0.3 \%$ and $0.4 \%$ in laparoscopic cholecystectomy ${ }^{8}$. In the present study, we excluded from the analysis patients

Table 4. Peak expiratory flow values before and after surgery according to comorbidities. Different letters indicate statistically distinct groups.

\begin{tabular}{lccc}
\hline & \multicolumn{3}{c}{ Time } \\
\cline { 2 - 3 } Comorbidity & Preoperative PFE & & Postoperative PFE \\
\cline { 2 - 3 } Absent $(n=18)$ & $466.1 \pm 98.9 \mathrm{~A}$ & & $389.5 \pm 96.2 \mathrm{C}$ \\
HT $(n=17)$ & $382.9 \pm 71.0 \mathrm{~B}$ & & $295.0 \pm 56.9 \mathrm{D}$ \\
DM $(\mathrm{n}=4)$ & $387.5 \pm 78.9 \mathrm{AB}$ & & $292.5 \pm 70.9 \mathrm{CD}$ \\
HT + DM $(n=8)$ & $365.0 \pm 69.7 \mathrm{~B}$ & & $295.0 \pm 66.1 \mathrm{D}$ \\
\hline
\end{tabular}

HT: Hypertension; DM: Diabetes. 
Table 5. Peak expiratory flow values after surgery according to the different types of surgery. Different letters indicate statistically distinct groups.

\begin{tabular}{lc}
\hline \multicolumn{1}{c}{ Type of surgery } & Postoperative PFE \\
\cline { 2 - 2 } Videocholecystectomy $(n=40)$ & $345.2 \pm 85.6 \mathrm{~A}$ \\
Conventional cholecystectomy $(n=4)$ & $275.0 \pm 52.6 \mathrm{~A}$ \\
Incisional Herniorrhaphy $(n=2)$ & $225.0 \pm 21.2 \mathrm{~A}$ \\
Gastrectomy $(n=1)$ & $200.0 \mathrm{~A}$ \\
\hline
\end{tabular}

who had some postoperative complications, not recording data about such conditions.

In addition to the surgical site, other factors also stand out, such as advanced age, presence of pulmonary disease or other medical illnesses, smoking and its intensity, obesity, malnutrition, type of anesthesia, duration of surgery and surgical technique, abnormal spirometry values, decreased ability to exercise and prolonged time of preoperative hospitalization ${ }^{1,2}$.

Anesthesia, bed rest, phrenic nerve dysfunction, surgical trauma and pain affect respiratory muscle function after surgery, inducing a shallow, monotonous breathing pattern, without periodic physiological sighs. With the reduction of breathing efficiency, there is a decrease in vital capacity, functional residual capacity, tidal volume and forced expiratory volume in one second, factors that may facilitate the onset of pulmonary complications ${ }^{9}$. Thus, prior knowledge of these values in the preoperative period may allow the diagnosis and quantification of ongoing ventilatory disorders, preventing possible respiratory complications in the postoperative period ${ }^{10}$.

The primary goal of preoperative pulmonary assessment is precisely to identify, quantify and reduce the risk of such complications ${ }^{9}$.

The peak of postoperative diaphragm dysfunction occurs in the period between two to eight hours after surgery, returning to preoperative values in seven to ten days, interfering in most spirometric values, including $\mathrm{PEF}^{10}$.

Silva et al. evaluated pre and postoperative PEF values in patients undergoing upper abdominal floor surgery and found a significant decrease of this variable, as well as smaller PEF values in females, data similar to those obtained in our study ${ }^{11}$.

According to Filardo et al., in the patient preoperative evaluation, some important variables have been associated with increased risk for POLC: advanced age, presence of pulmonary disease or other comorbidities, smoking and its intensity, obesity and malnutrition'.

Pereira et al. studied the incidence of pulmonary complications in the postoperative period of 408 patients undergoing upper abdominal surgery and identified several risk factors that associated with these complications. From there, they formulated a prognostic index, which included the presence of comorbidities (hypertension and/or diabetes) as one of the elements favorable to the emergence of POLC and decrease in spirometric values $^{12}$

Both mentioned studies considered the presence of advanced age, smoking and comorbid conditions as some of the main factors related to changes in ventilatory function both pre and postoperatively, and such results agree with those obtained in this study.

In older studies (1984 and 1989), on the other hand, Warner et al. found that patients who still smoked or stopped smoking less than two months before surgery had complication rates about four times higher than patients who had stopped smoking more than two months before surgery, and all had greater impairment of ventilatory function regardless of which examination was held $^{13}$. These data corroborate our study, which showed that smoking is inversely correlated to pre and postoperative PEF.

Table 6. Peak expiratory flow values after surgery according to anesthetic technique. Different letters indicate statistically distinct groups.

\begin{tabular}{lc}
\hline \multicolumn{1}{c}{ Type of anesthesia } & Postoperative PFE \\
\cline { 2 - 2 } General $(n=41)$ & $335.1 \pm 88.5 \mathrm{~A}$ \\
General + epidural $(n=3)$ & $270.0 \pm 55.7 \mathrm{~A}$ \\
\hline
\end{tabular}


We conclude from our survey that the most involved variables in the decrease in ventilatory function were the same found in the literature, such as advanced age, smoking status and presence of comorbidities. However, there are still no significant evidence to suggest routinely conducting preoperative breath tests for such patients and each case should be individualized and evaluated by a specialist when necessary, a conduct adopted in the HRMS. The study reinforces the importance of greater attention to the ventilatory function in this patients group, which can determine interventions that reduce the morbidity and mortality rates related to POLC

\title{
R E S U M O
}

\begin{abstract}
Objetivo: avaliação comparativa da função ventilatória através do Pico de Fluxo Expiratório (PFE) no pré e pós-operatório imediatos de pacientes submetidos a procedimentos cirúrgicos eletivos do andar superior do abdome. Métodos: estudo prospectivo de coorte incluindo 47 pacientes internados no Hospital Regional de Mato Grosso do Sul de Julho à Dezembro de 2014, e que realizaram cirurgias eletivas do andar superior do abdome, e submetidos à avaliação espirométrica e aferição do PFE no pré e pós operatório imediatos. Resultados: dos 47 pacientes, 22 (46,8\%) eram do sexo masculino, e 25 (53,20\%) do sexo feminino. A média do PFE pré-operatório foi 412, 1土91,7, e do pós-operatório de $331,0 \pm 87,8$, indicando diferenças significantes entre as duas variáveis. O sexo masculino apresentou maiores valores de PFE do que o feminino, tanto no pré-cirúrgico quanto no pós-cirúrgico. Observou-se razoável correlação inversamente proporcional entre as variáveis idade e diminuição do PFE. Ambas as situações mostraram significância estatística ( $p<0,001)$. O grupo composto por fumantes apresentou menores valores de PFE tanto no pré como no pós-operatório. O grupo composto por portadores de co-morbidades (HAS e/ou $D M)$ apresentou menores valores de PFE tanto no pré como no pós-operatório $(p=0,005)$. Em ambos os grupos, o pós-operatório determinou uma diminuição significativa do PFE $(p<0,001)$. O tipo de cirurgia realizada e o tipo de anestesia não mostraram diferenças significantes em relação ao PFE. Conclusão: as variáveis mais implicadas na diminuição da função ventilatória, avaliadas através da PFE, foram: idade avançada, tabagismo e presença de comorbidades.
\end{abstract}

Descritores: Pico de Fluxo Expiratório. Cirurgia. Tabagismo. Cirúrgia Torácica. Procedimentos Cirúrgicos Eletivos.

\section{REFERENCES}

1. Filardo, FA, Faresin SM, Fernandes ALG. Validade de um índice prognóstico para ocorrência de complicações pulmonares no pós-operatório de cirurgia abdominal alta. Rev Assoc Med Bras. 2002;48(3):209-16.

2. Barros JA, Beppu OS, Chueiri CEB, Pereira EDB, Faresin SM, Ferreira MS, et al. Incidência de complicações pulmonares e mortalidade de causa pulmonar em candidatos à cirurgia geral. J Pneumol. 1992;18(supl 2):108

3. Stein M, Koota GM, Simon M, Frank HA. Pulmonary evaluation of surgical patients. JAMA. 1962;181:765-70.

4. Sociedade Brasileira de Pneumologia e Tisiologia. Diretrizes para testes de função pulmonar. J Pneumol. 2002;28(Suppl 3):S1-S238.

5. Rock P, Rich PB. Postoperative pulmonary complications Curr Opin Anaesthesiol, 2003;16(2):123-31.

6. Fisher BW, Majumdar SR, McAlister FA. Predicting pulmonary complications after nonthoracic surgery: a systematic review of blinded studies. Am J Med. 2002;112(3):219-25.
7. Lawrence VA, Hilsenbeck SG, Mulrow CD, Dhanda R, Sapp J, Page CP. Incidence and hospital stay for cardiac and pulmonary complications after abdominal surgery. J Gen Intern Med. 1995; 10(12):671-8

8. Smetana GW. Preoperative pulmonary evaluation. N Engl J Med. 1999;340(12):937-44.

9. Warner DO. Preventing postoperative pulmonary complications: the role of the anesthesiologist. Anesthesiology. 2000;92(5):1467-72.

10. Siafakas NM, Mitrouska I, Bouros D, Georgopoulos $D$. Surgery and the respiratory muscles. Thorax. 1999;54(5):458-65.

11. Silva DR, Baglio PT, Gazzana MB, Barreto SSM. Avaliação pulmonar e prevenção das complicações respiratórias perioperatórias. Rev Bras Clin Med. 2009;7:114-23.

12. Pereira EDB, Fernandes ALG, Anção MS, Peres CA, Atallah AN, Faresin SM. Prospective assessment of the risk of postoperative pulmonary complications in patients submitted to upper abdominal surgery. Sao Paulo Med J. 1999;117(4):151-60. 
13. Warner MA, Offord KP, Warner ME, Lennon RL, Conover MA, Jansson-Schumacher $U$. Role of preoperative cessation of smoking and other factors in postoperative pulmonary complications: a blinded prospective study of coronary artery bypass patients. Mayo Clin Proc. 1989;64(6):609-16.
Recebido em: 13/02/2016

Aceito para publicação em: 21/04/2016 Conflito de interesse: nenhum.

Fonte de financiamento: nenhuma.

\section{Endereço para correspondência:}

Caio Fernando Cavanus Scheeren

E-mail: caioscheeren@hotmail.com 